\title{
Preparation of hydroxyapatite-ferrite composite particles by ultrasonic spray pyrolysis
}

\author{
Naoki Wakiya ${ }^{1 *}$, Maya Yamasaki ${ }^{1}$, Tomoyuki Adachi ${ }^{1}$, Akihiro Inukai ${ }^{1}$, Naonori \\ Sakamoto $^{1}$, Desheng Fu ${ }^{2}$, Osamu Sakurai ${ }^{3}$, Kazuo Shinozaki ${ }^{3}$, and Hisao Suzuki ${ }^{2}$ \\ ${ }^{1}$ Department of Materials Science and Chemical Engineering, Shizuoka University, \\ 3-5-1 Johoku Naka-ku, Hamamatsu 432-8561, JAPAN \\ ${ }^{2}$ Graduate School of Materials Science and Technology, Shizuoka University, Address, \\ 3-5-1 Johoku Naka-ku, Hamamatsu 432-8561, JAPAN \\ ${ }^{3}$ Department of Metallurgy and Ceramics Science, Tokyo Institute of Technology, \\ 2-15-1 O-okayama Meguro-ku, Tokyo 152-8550, JAPAN
}

\begin{abstract}
Biocompatible composite particles composed of hydroxyapatite $\left(\mathrm{Ca}_{10}\left(\mathrm{PO}_{4}\right)_{6}(\mathrm{OH})_{2}\right.$, HAp) and ferrite (maghemite $\left(\gamma-\mathrm{Fe}_{2} \mathrm{O}_{3}\right)$ or magnetite $\left.\left(\mathrm{Fe}_{3} \mathrm{O}_{4}\right)\right)$ were synthesized by two-step synthesis. In this work, co-precipitation method using aqueous solution of $\mathrm{FeSO}_{4}$ and $\mathrm{FeCl}_{3}$ was employed to synthesize $\gamma-\mathrm{Fe}_{2} \mathrm{O}_{3}$ and $\mathrm{Fe}_{3} \mathrm{O}_{4}$ particles. It was found that the resultant phase was changed by the molar ratio of $\mathrm{FeSO}_{4}$ and $\mathrm{FeCl}_{3}$, and optimal molar ratio to suppress the coexistence of $\underline{\alpha-\mathrm{FeOOH}}$ was $\mathrm{FeSO}_{4} / \mathrm{FeCl}_{3}=2$. The suspension composed of crushed ferrite particles, $\mathrm{Ca}\left(\mathrm{NO}_{3}\right)_{2}$ and $\mathrm{H}_{3} \mathrm{PO}_{4}$ aqueous solution with surfactant ultrasonically nebulized into mist and the mist was pyrolyzed at $\underline{500^{\circ} \mathrm{C}}$ to synthesize HAp-ferrite composite particles. The shape of the synthesized
\end{abstract}


composite particle was round with dimple, and the particle size was around $0.5-3 \mu \mathrm{m}$ in diameter. The composite particle showed saturation magnetization of $0.833 \mathrm{emu} / \mathrm{g}$. Net saturation magnetization of the ferrite component was calculated to be 46.4 or 48.0 $\mathrm{emu} / \mathrm{g}$ under the assumption that the ferrite was composed of $\gamma-\mathrm{Fe}_{2} \mathrm{O}_{3}$ or $\mathrm{Fe}_{3} \mathrm{O}_{4}$, respectively. 


\section{Introduction}

Ferrite nanoparticles have been used for many biomedical applications such as media for biosensors[1-8], hyperthermia[9,10], magnetic resonance imaging[11,12], immunoassay[13,14] and magneto-targeting carrier for drug delivery system (DDS) $[15,16]$ etc. For these applications, it is important to ensure the biocompatibility since the ferrite nanoparticles should be introduced into the blood vessels. Therefore, the surface of the ferrite nanoparticles has been coated with biocompatible materials such as gold $(\mathrm{Au})[17,18]$, polymer [19,20], silica $\left(\mathrm{SiO}_{2}\right)[21,22]$, titania $\left(\mathrm{TiO}_{2}\right)[23]$ and hydroxyapatite $\left(\mathrm{Ca}_{10}\left(\mathrm{PO}_{4}\right)_{6}(\mathrm{OH})_{2}\right.$, HAp) [24-27]. Among these, HAp coated core/shell structured ferrite nanoparticles is one of the most promising materials. Deb et al. [24] reported the synthesis of HAp-coated hexaferrite of $(\mathrm{CaO})_{0.75}\left(\mathrm{La}_{2} \mathrm{O}_{3}\right)_{0.20}\left(\mathrm{Fe}_{2} \mathrm{O}_{3}\right)_{6}$ particles. However hexaferrite has high coercive force that is not suitable for bio-medical application due to the possibility of magnetic agglomeration. Tang et al. reported the synthesis of core/shell structured nanoparticles with HAp and Mn- or Co-ferrite [25-27]. They synthesized the nanoparticles by co-precipitation method using mixture of aqueous solutions of $\mathrm{Ca}\left(\mathrm{NO}_{3}\right)_{2} \cdot 4 \mathrm{H}_{2} \mathrm{O}, \underline{\left(\mathrm{NH}_{4}\right)_{2}} \underline{\mathrm{HPO}}_{4}, \mathrm{Fe}\left(\mathrm{NO}_{3}\right)_{3} \cdot 9 \mathrm{H}_{2} \mathrm{O}$ and $\mathrm{MnCl}_{2} \cdot 4 \mathrm{H}_{2} \mathrm{O}$ or $\mathrm{Co}\left(\mathrm{NO}_{3}\right)_{2}$, and $\left(\mathrm{NH}_{4}\right) \mathrm{OH}$. This means that both HAp and ferrite nanoparticles are precipitated at the same time, and the core/shell structure was realized 
by one-step procedure using phase separation during heat treatment. Chen et al. reported HAp coated $\mathrm{SiO}_{2}$ nanoparticles [28]. They soaked sol-gel derived $\mathrm{SiO}_{2}$ nanoparticles in the Kokubo's simulated body fluid (SBF) [29] to obtain core/shell structure. Therefore, their procedure can be classified into two-step procedure.

The purpose of this work is to synthesize HAp-ferrite composite particles by the combination of co-precipitation and ultrasonic spray pyrolysis since ultrasonic pyrolysis has the advantage to control the composition of multi-component oxide powders, and the method is suitable for future mass production. HAp nanoparticles have been synthesized by ultrasonic spray pyrolysis [30-33]. In this work, two-step synthesis was used to synthesize HAp-ferrite composite. First step is to synthesize ferrite nanoparticles by co-precipitation method, and second step is synthesis of HAp and ferrite composite nanoparticles by ultrasonic spray pyrolysis.

\section{Experimental}

Reagent grade $\mathrm{FeSO}_{4} \cdot 7 \mathrm{H}_{2} \mathrm{O}$ and $\mathrm{FeCl}_{3}$ were weighed and dissolved in the $60 \mathrm{ml}$ deionization water. The composition of the solution was changed according to $\mathrm{xFeSO}_{4} \cdot 7 \mathrm{H}_{2} \mathrm{O}-(100-\mathrm{x}) \mathrm{FeCl}_{3}(0 \leq \mathrm{x} \leq 1)$. Total concentration of $\mathrm{Fe}$ in the solution was kept at $0.075 \mathrm{~mol} / \mathrm{l}$. To carry out co-precipitation, $30 \mathrm{ml} \mathrm{NaOH}$ aqueous solution $(1 \mathrm{~mol} / \mathrm{l})$ was dropped slowly at the dropping rate of $3 \mathrm{ml} / \mathrm{min}$. After the co-precipitation, the 
supernatant solution was removed, and deionization water was added to wash the sediment. Then the sediment was centrifugally separated. This washing procedure was repeated 3 times. Then the sediment was filtrated and dried at $200^{\circ} \mathrm{C}$. Dried sediment was crushed by planetary milling in ethanol using $2 \mathrm{~mm} \phi$ yttria stabilized zirconia (YSZ) balls in the YSZ pod for $30 \mathrm{~h}$ at $100 \mathrm{rpm}$. The crushed sediment was added in the deionization water with $0.02 \mathrm{~mol} / 1$ cetyltrimethyl ammonium bromide (CTAB) surfactant to prepare suspension since Liu et al. reported the validity of CTAB addition to prepare suspension of maghemite $\left(\gamma-\mathrm{Fe}_{2} \mathrm{O}_{3}\right)$ [34]. The suspension $(100 \mathrm{ml})$ containing $0.5 \mathrm{~mol} / 1 \gamma-\mathrm{Fe}_{2} \mathrm{O}_{3}$ (where all $\mathrm{Fe}$ was considered to be $\gamma-\mathrm{Fe}_{2} \mathrm{O}_{3}$ form), and the suspension was mixed with the $0.5 \mathrm{~mol} / \mathrm{l} \mathrm{HAp}$ source solution $(100 \mathrm{ml})$, and precursor for ultrasonic spray pyrolysis was prepared where HAp source solution was consisted of $\mathrm{Ca}\left(\mathrm{NO}_{3}\right)_{2} \cdot 4 \mathrm{H}_{2} \mathrm{O}, \mathrm{H}_{3} \mathrm{PO}_{4}$ and 5 mass $\%$ of $\mathrm{NaNO}_{3}$. Prior to ultrasonic spray pyrolysis, the precursor was ultrasonically homogenized for 8 hours using ultrasonic homogenizer. Then the precursor was nebulized using 1.6 MHz ultrasonic nebulizer and the generated aerosol was transported by $\mathrm{N}_{2}$ carrier gas $(5 \mathrm{l} / \mathrm{min})$ into furnace for drying at $100^{\circ} \mathrm{C}$ followed by furnace for decomposition at $500^{\circ} \mathrm{C}$. After the decomposition, the particles were collected by filter.

Crystal structure of the samples was examined using an X-ray diffractometer 
equipped with a $\mathrm{Cu}$ anode (D8 Advance, Bruker) and phase composition was analyzed using TOPAS software [35]. Magnetic property of the samples was examined by vibration sample magnetometer (VSM)(BHV-35, Riken denshi) measured at room temperature with maximum magnetic field of $10 \mathrm{kOe}$ and frequency of $25 \mathrm{~Hz}$. The magnetization was calibrated using standard sample of Ni foil. The composition of the composite particles was measured using an inductively coupled plasma atomic emission spectrometer (ICP-AES) (Optima 2100DV, Perkin Elmer). Prior to ICP-AES measurement, the film was dissolved in hydrochloric acid.

\section{Results and discussion}

Figures 1 (a)-(e) show the change of XRD patterns of co-precipitated particles after drying at $200^{\circ} \mathrm{C}$ with the composition $x$ in molar $\%$ of $\mathrm{FeSO}_{4} \cdot 7 \mathrm{H}_{2} \mathrm{O}$ $\left(\mathrm{xFeSO}_{4} \cdot 7 \mathrm{H}_{2} \mathrm{O}-(100-\mathrm{x}) \mathrm{FeCl}_{3}\right.$. In these figures, we gave same mark (closed circle) for both $\mathrm{Fe}_{3} \mathrm{O}_{4}$ (cubic spinel structure) and $\gamma-\mathrm{Fe}_{2} \mathrm{O}_{3}$ (tetragonal) because the diffraction patterns of $\mathrm{Fe}_{3} \mathrm{O}_{4}$ and $\gamma-\mathrm{Fe}_{2} \mathrm{O}_{3}$ are very close. These figures indicate that the single phase $\alpha-\mathrm{FeOOH}$ (goethite) was obtained at $\mathrm{x}=0$ (Fig.1(a)), and coexistence of $\alpha-\mathrm{FeOOH}$ was clearly observed at $\mathrm{x}=33.3$ and 100 (Figs. 1(b) and (e)). Figure 1 also shows that predominant phase at $\mathrm{x}>33.3$ is spinel structure including $\mathrm{Fe}_{3} \mathrm{O}_{4}$ (magnetite) 
and $\gamma-\mathrm{Fe}_{2} \mathrm{O}_{3}$ (maghemite). The amount of $\mathrm{Fe}_{3} \mathrm{O}_{4}, \gamma-\mathrm{Fe}_{2} \mathrm{O}_{3}$ and $\alpha-\mathrm{FeOOH}$, and each crystallite size was determined using TOPAS software, and the results were shown in Fig. 2 as the function of composition x. Figure 2(a) indicates that predominant phase in spinel structure is not $\mathrm{Fe}_{3} \mathrm{O}_{4}$ but $\gamma-\mathrm{Fe}_{2} \mathrm{O}_{3}$ in the composition range is $33.3 \leq \mathrm{x} \leq 100$. It was also clarified that the coexistence of $\alpha-\mathrm{FeOOH}$ was detected for all compositions, and minimum value of coexistence of $\alpha-\mathrm{FeOOH}$ was realized at $\mathrm{x}=66.7$. This figure indicates that the amount of $\alpha-\mathrm{FeOOH}$ increased for $\mathrm{x}=100$ compared to $\mathrm{x}=66.7$. As the reason, we consider that both divalent and trivalent $\mathrm{Fe}$ is needed to crystallize as the spinel structure. For the sample $\mathrm{x}=100$, no trivalent $\mathrm{Fe}$ exists at the initial stage. Therefore, to form spinel structure, oxidation of divalent Fe into trivalent Fe is needed. However, the oxidation of divalent Fe into trivalent Fe predominantly occurs at the surface layer of solution. Some trivalent Fe diffuses into bulk layer to form spinel structure, however; most of trivalent Fe remains at the surface layer to form $\alpha-\mathrm{FeOOH}$ because the concentration of trivalent Fe in the surface layer is high. Figure 2(b) depicts that crystallite size of both $\mathrm{Fe}_{3} \mathrm{O}_{4}$ and $\gamma-\mathrm{Fe}_{2} \mathrm{O}_{3}$ increase with composition, and crystallite sizes of $\mathrm{Fe}_{3} \mathrm{O}_{4}$ and $\gamma-\mathrm{Fe}_{2} \mathrm{O}_{3}$ at $\mathrm{x}=66.7$ are 30.5 and $17.6 \mathrm{~nm}$, respectively. In the following experiments, composition $\mathrm{x}=66.7$ was used since the amount of impurity phase $(\alpha-\mathrm{FeOOH})$ was minimum. 
The suspension including crushed ferrites (mixture of $\gamma-\mathrm{Fe}_{2} \mathrm{O}_{3}$ and $\mathrm{Fe}_{3} \mathrm{O}_{4}$ ), CTAB, $\mathrm{Ca}\left(\mathrm{NO}_{3}\right)_{2} \cdot 4 \mathrm{H}_{2} \mathrm{O}, \mathrm{H}_{3} \mathrm{PO}_{4}$ and $\mathrm{NaNO}_{3}$ was ultrasonically spray pyrolyzed at $500^{\circ} \mathrm{C}$, and the sample was collected. Figure 3 shows XRD pattern of the resultant particles. This figure indicates that predominant phase is HAp, and small amount of ferrite was also found. This indicates that composite of HAp and ferrite was synthesized. To determine the amount of HAp and ferrite, the composite particles were dissolved in $\mathrm{HCl}$ and the composition was analyzed by ICP-AES, and the result was shown in Table I. In the Table I, prescribed composition was also shown. This table shows that incorporation efficiency of ferrite particles into HAp matrix is $11.5 \%$. This table also indicates that molar ratio of $\mathrm{Ca} / \mathrm{P}=1.63$ and this value is almost close to that of source solution and stoichiometric $\mathrm{HAp}(\mathrm{Ca} / \mathrm{P}=1.67)$. This table indicates that molar ratio of $\gamma-\mathrm{Fe}_{2} \mathrm{O}_{3} / \mathrm{HAp}$ becomes 0.115 if all $\mathrm{Fe}$ ions are supposed to be incorporated in the $\gamma-\mathrm{Fe}_{2} \mathrm{O}_{3}$. Similarly, if all $\mathrm{Fe}$ ions are supposed to be incorporated in the $\mathrm{Fe}_{3} \mathrm{O}_{4}$, the molar ratio of $\mathrm{Fe}_{3} \mathrm{O}_{4} / \mathrm{HAp}$ becomes 0.0767 . Figure 4 shows $\mathrm{M}-\mathrm{H}$ curve of the HAp-ferrite composite particles measured at room temperature. In this figure magnetization was calculated using total weight of the sample including HAp and ferrite. This figure depicts that saturation magnetization of the composite is $0.833 \mathrm{emu} / \mathrm{g}$. To estimate the state of ferrite, the $\mathrm{M}-\mathrm{H}$ curve was calculated on the assumption that all $\mathrm{Fe}$ ions are incorporated in $\gamma-\mathrm{Fe}_{2} \mathrm{O}_{3}$ and 
$\mathrm{Fe}_{3} \mathrm{O}_{4}$ is also shown as inset (a) and (b), respectively. Insets (a) and (b) indicate that saturation magnetization calculated on the assumption that all Fe ions are incorporated in $\gamma-\mathrm{Fe}_{2} \mathrm{O}_{3}$ and $\mathrm{Fe}_{3} \mathrm{O}_{4}$ turns out to be 46.4 and $48.0 \mathrm{emu} / \mathrm{g}$, respectively. These values are smaller than the bulk saturation magnetization of $82.4 \mathrm{emu} / \mathrm{g}$ for $\gamma-\mathrm{Fe}_{2} \mathrm{O}_{3}$ [36], and 92.1 $\mathrm{emu} / \mathrm{g}$ for $\mathrm{Fe}_{3} \mathrm{O}_{4}$ [37]. The lowering of magnetization compared with bulk suggests that diffusion of $\mathrm{Ca}$ into spinel structure occurred during spray pyrolysis process since this process is a reaction between solution and nanoparticles. To consider the diffusion of $\mathrm{Ca}$ into spinel structure, lattice parameter of $\mathrm{Fe}_{3} \mathrm{O}_{4}$ in the HAp-ferrite composite was calculated to be $\mathrm{a}=0.8466 \mathrm{~nm}$. This value is slight larger than that of pure $\mathrm{Fe}_{3} \mathrm{O}_{4}$ $(a=0.08394 \mathrm{~nm})[38]$ suggesting the diffusion of $\mathrm{Ca}$ into spinel structure since ionic radius of $\mathrm{Ca}^{2+}\left(0.100 \mathrm{~nm}\right.$ in 6-fold coordination) is larger than that of $\mathrm{Fe}^{2+}(0.078 \mathrm{~nm}$ in 6-fold coordination) [39]. Actually, the lowering of magnetization by substitution of Fe by $\mathrm{Ca}$ has been reported by Park et al. [40]. Figure 4 also shows that the coercive force of synthesized HAp-ferrite composite is around 120 Oe. This value is smaller than the coercive force reported for single-domain magnetite particles $(270$ Oe) [41]. This decrease of coercive force can be attributed to the grain size of the ferrite particles. As the particle size is reduced, the density of magnetic bonds decreases as long as the proportion of undercoordinated ions on the surface becomes grater. Therefore, smaller 
fields enable more easily the reversal of spins and lead to lower switching fields for smaller sizes [42].

Concerning to the diffusion, we also consider the possibility of the substitution of $\mathrm{Ca}^{2+}$ with $\mathrm{Fe}^{2+}$ in HAp. Lattice parameter of HAp in HAp-ferrite composite is a $=0.94098 \mathrm{~nm}$ and $\mathrm{c}=0.68917 \mathrm{~nm}$ (cell volume of $1.585 \mathrm{~nm}^{3}$ ). On the other hand, lattice parameter of pure HAp has been reported to be $\mathrm{a}=0.9424 \mathrm{~nm}$ and $\mathrm{c}=0.6879 \mathrm{~nm}$ (cell volume of 1.587 $\mathrm{nm}^{3}$ ) [43]. The fact that lattice parameter is slightly changed suggests the partial substitution; however, the amount of substitution is almost negligible since cell volume of HAp is almost unchanged.

Figure 5 shows SEM photograph of the HAp-ferrite composite particles. This photograph indicates that the composite particles have round shape with some dimples that is characteristic for powder synthesized by spray pyrolysis. The particle size was around between 0.5 and $3 \mu \mathrm{m}$ with average particle size of around $1.8 \mu \mathrm{m}$. We estimated the thickness of shell and the radius of the core on the assumption that all HAp-ferrite composite particles have core/shell structure, and the core and shell is composed of ferrite and HAp, respectively. For this estimation, the composition shown in Table I was 
used. As the result, the thicknesses of the shell and the radius of core were turned out to be 1.5 and $0.3 \mu \mathrm{m}$, respectively. Now we are trying to observe cross sectional TEM image of the HAp-ferrite composite particles to ascertain the microstructure.

In this work, we tried to synthesize core/shell type HAp-ferrite composite particles. However, another type of composite such as mechanical mixture of HAp and ferrite also serve as the our final target of novel drug-delivery and hyperthermia. Now we also synthesizing this type of composite using planetary milling; however, in this case, ferrite particles are partially exposed on the surface of the composite particle, and lowering of the bio-compatibility would be expected. Therefore, from the point of bio-compatibility, we believe that core/shell type composite is safer than that synthesized by mechanical mixture.

\section{Conclusions}

We synthesized HAp-ferrite composite particles using two-step synthesis. First step is to synthesize ferrite particles by co-precipitation of $\mathrm{FeSO}_{4}$ and $\mathrm{FeCl}_{3}$ aqueous solutions. The ferrite was mainly composed of maghemite $\left(\gamma-\mathrm{Fe}_{2} \mathrm{O}_{3}\right)$ and magnetite $\left(\mathrm{Fe}_{3} \mathrm{O}_{4}\right)$. Second step is to synthesize HAp-ferrite composite particles by ultrasonic spray pyrolysis at $500^{\circ} \mathrm{C}$ using suspension composed of crushed ferrite particles and $\mathrm{Ca}\left(\mathrm{NO}_{3}\right)_{2}$ 
and $\mathrm{H}_{3} \mathrm{PO}_{4}$. Formation of HAp-ferrite composite was confirmed by $\mathrm{X}$-ray diffraction, composition analysis and magnetic property measurements. The saturation magnetization of ferrite in the HAp-ferrite composite was 46.4 or $48.0 \mathrm{emu} / \mathrm{g}$ under the assumption that ferrite component was composed of $\gamma-\mathrm{Fe}_{2} \mathrm{O}_{3}$ or $\mathrm{Fe}_{3} \mathrm{O}_{4}$, respectively. The values of saturation magnetization suggested that partial substitution of $\mathrm{Ca}$ would occur in the ferrite. 


\section{Acknowledgement}

The authors wish to thank Prof. Junzo Tanaka and Tomohiko Yoshioka of Tokyo Institute of Technology for fruitful discussion concerning to this work.

The authors also thank Dr. K. Saito and T. Yamauchi of Bruker AXS for the help of X-ray diffraction measurement. 


\section{References}

[1] Wanling Xu and John Ketterson, J. Appl. Phys., 104 (2008) 044701-1-044701-5

[2] P.M. Levine, P.Gong, R. Levicky, K.L. Shepard, Biosensors and Bioelectronics 24 (2009) 1995-2001.

[3] B.W. Lu, W.C. Chen, J. Magn. Magn. Mater. 304 (2006) e400-e402.

[4] H. Chiriac, D.D. Herea, S. Corodeanu, J. Magn. Magn. Mater. 311 (2007) 425-428.

[5] M.M. Miller P.E. Sheehan, R.L. Edelstein, C.R. Tamanaha, L. Zhong, S. Bounnak, L.J. Whitman, R.J. Colton, J. Magn. Magn. Mater. 225 (2001) 138-144.

[6] B.D. Tu, T. Q. Hung, N.T. Thanh, T.M. Danh, N. H. Duc, C.G. Kim, J. Appl. Phys. 104 (2008) 074701-1-074701-4.

[7] S. Wu, X. Gao, Q. Cai, C. A. Grimes, Sensors and Actuators B 123 (2007) 856-859.

[8] S.G. Grancharov, H. Zeng, S. Sun, S.X. Wang, S. O’Brien, C.B. Murray, J.R. Kirtley, G. A. Held, J. Phys. Chem. B 109 (2005) 13030-13035.

[9] D.H. Kim, Y.K. Lee, J. Mater. Sci. 39 (2004) 6847-6850.

[10] A. Jordan, P. Wust, H. Fähling, W. John, A. Hinz, R. Felix, Int. J. Hyperthermia 9 (1993) 51-68.

[11] R. Weisseleder, A. Bogdanov, E.A. Neuwelt, M. Papisov, Adv. Drug Delivery Rev. 16 (1995) 321-334.

[12] C.M. Fu, Y.F. Wang, Y.F. Guo, T.Y. Lin, J.S.Chiu, IEEE Trans. Magn. 41 (2005) 4120-4122.

[13] I. Nishizono, S. Iida, N Suzuki, H. Kawada, H. Murakami, Y. Ashihara, M. Okada, Clinical Chem. 37 (1991) 1639-1644.

[14] J.W. Choi, C.H. Ahn, S. Bhansali, H.T. Henderson, Sensors and Actuators B: Chem. Volume 68 (2000) 34-39.

[15] P. Gould, Materialstoday 7 (2004) 36-43.

[16] M. Maeda, C. S. Kuroda, T. Shimura, M. Tada, and M. Abe, S. Yamamuro and K. Sumiyama, H. Handa, J. Appl. Phys. 99 (2006) 08H103-1-08H103-3.

[17] I.I. S. Lim, P.N. Njoki, H.Y. Park, X.Wang, L. Wang, D. Mott, C.J. Zhong, Nanotechnology 19 (2008) 305102-1-305102-11.

[18] I.Y. Goon, L.M.H. Lai, M. Lim, P. Munroe, J. J. Gooding, R. Amal, Chem. Mater. 21 (2009) 673-681.

[19] V. Belessi, R. Zboril, J. Tucek, M. Mashlan, V. Tzitzios, D. Petridis, Chem. Mater. 20 (2008) 3298-3305.

[20] N. Shamim, L. Hong, K. Hidajat, M.S. Uddin, Separation and Purification Technol. 53 (2007) 164-170.

[21] Z. Liu, Y. Liu, H. Yang, Y. Yang, G. Shen, R. Yu, Anal. Chim. Acta 533 (2005) 
3-9.

[22] B. Liu, W. Xie, D. Wang, W. Huang, M. Yu, A. Yao, Mater. Lett. 62 (2008) 30143017.

[23] Y.S. Chung, S.B. Park, D.W. Kang, Mater. Chem. Phys. 86 (2004) 375-381.

[24] S. Deb, J. Giri, S. Dasgupta, D. Datta, D. Bahadur, Bull. Mater. Sci. 26 (2003) 655-660.

[25] W. Pon־on, S. Meejoo, I.M. Tang, Int. J. Nanosci. 6 (2007) 9-16.

[26] W. Pon-on, S. Meejoo, I.M. Tang, Mater. Res. Bull. 43 (2008) 1237-2144.

[27] N. Petchsang, W. Pon-On, J.H. Hodak, I.M. Tang, J. Magn. Magn. Mater. 321 (2009) 1990-1995.

[28] S. Chen, A. Osaka, S. Hayakawa, K. Tsuru, E. Fujii, K. Kawabata, J. Sol-Gel Sci. Technol. 48 (2008) 322-335.

[29] T. Kokubo, H. Takadama, Biomater. 27 (2006) 2907-2915.

[30] D. Veilleux, N. Barthelemy, J.C. Trombe, M. Verelst, J. Mater. Sci. 36 (2001) 2245-2252.

[31] J. Barralet, J.C. Knowles, S. Best, W. Bonfield, J. Mater. Sci. Mater. In Medicine 13 (2002) 529-533.

[32] J.S. Cho, Y.C.Kang, J. Alloys and Compounds 464 (2008) 282-287.

[33] G.H. An, H.J. Wang, B.H. Kim, Y.G. Jeong, Y.H. Choa, Mater. Sci. Eng. A 449-451 (2007) 821-824.

[34] T. Liu, L. Guo and Y. Tao, Nano Structured Mater. 11 (1999) 487-492.

[35] A.A. Coelho, J. Appl. Cryst. 33 (2000) 899-908.

[36] R. Hergt, R. Hiergeist, M. Zeisberger, G. Glöckl, W. Weitscies, L.P. Ramirez, I. Hilger, W.A. Kaiser, J. Magn. Magn. Mater. 280 (2004) 358-368.

[37] R.J. Kennedy, P.A. Stampe, J. Phys. D: Appl. Phys. 32 (1999) 16-21.

[38] M.E. Fleet, Acta Cryst. B 37 (1981) 917-920.

[39] R.D. Shannon, Acta. Cryst. A 32 (1976) 751-767.

[40] S.I. Park, J.H. Lim, Y.H. Hwang, J.H. Kim, C.G. Kim, C.O. Kim, Phys. Stat. Sol. 204 (2007) 3913-3917.

[41] D.B. Bonstrom, A.H. Morrish, L.A.K. Watt, J. Appl. Phys. 32 (1961) S272-S272.

[42] J. Mazo-Zuluaga, J. Restrepo, F. Munoz, J. Mejia-Lopez, J. Appl. Phys. 105 (2009) 123907-1-123907-10

[43] K. Sudarsanan and R.A. Young, Acta Cryst. B 25 (1969) 1534-1543. 


\section{List of captions}

Table I. Composition of prescribed and analytical HAp-ferrite composite particles.

Fig. 1, Change of XRD pattern of co-precipitated particles after drying at $200^{\circ} \mathrm{C}$ with composition $\mathrm{x}$ in $\mathrm{xFeSO}_{4} \cdot 7 \mathrm{H}_{2} \mathrm{O}-(100-\mathrm{x}) \mathrm{FeCl}_{3}$. (a) $\mathrm{x}=0$, (b) $\mathrm{x}=33.3$, (c) $\mathrm{x}=50$, (d) $\mathrm{x}=66.7$, and $(e) x=100$.

Fig. 2. Change of (a) amount of phase and (b) crystallite size with composition $x$ in $\mathrm{xFeSO} \cdot \mathrm{SH}_{2} \mathrm{O}-(100-\mathrm{x}) \mathrm{FeCl}_{3}$. The amount of phase and crystallite size was measured using TOPAS software [35].

Fig. 3. XRD pattern of HAp-ferrite composite particles synthesized by two-step ultrasonic spray pyrolysis $(\mathrm{x}=66.7)$.

Fig. 4. M-H curve of HAp-ferrite composite particles synthesized by two-step ultrasonic spray pyrolysis. $\mathrm{M}-\mathrm{H}$ curve calculated on the assumption that all $\mathrm{Fe}$ ions are incorporated in $\gamma-\mathrm{Fe}_{2} \mathrm{O}_{3}$ and $\mathrm{Fe}_{3} \mathrm{O}_{4}$ is also shown as inset (a) and (b) ,respectively $(\mathrm{x}=66.7)$.

Fig. 5. SEM photograph of HAp-ferrite composite particles $(x=66.7)$. 
Table I. Composition of prescribed and analytical HAp-ferrite composite particles.

\begin{tabular}{cccc}
\hline & $\mathrm{Ca}(\mathrm{mol} \%)$ & $\mathrm{P}(\mathrm{mol} \%)$ & $\mathrm{Fe}(\mathrm{mol} \%)$ \\
\hline Prescribed composition & 55.6 & 33.3 & 11.1 \\
\hline Analytical composition (ICP-AES) & 61.1 & 37.5 & 1.4 \\
\hline
\end{tabular}




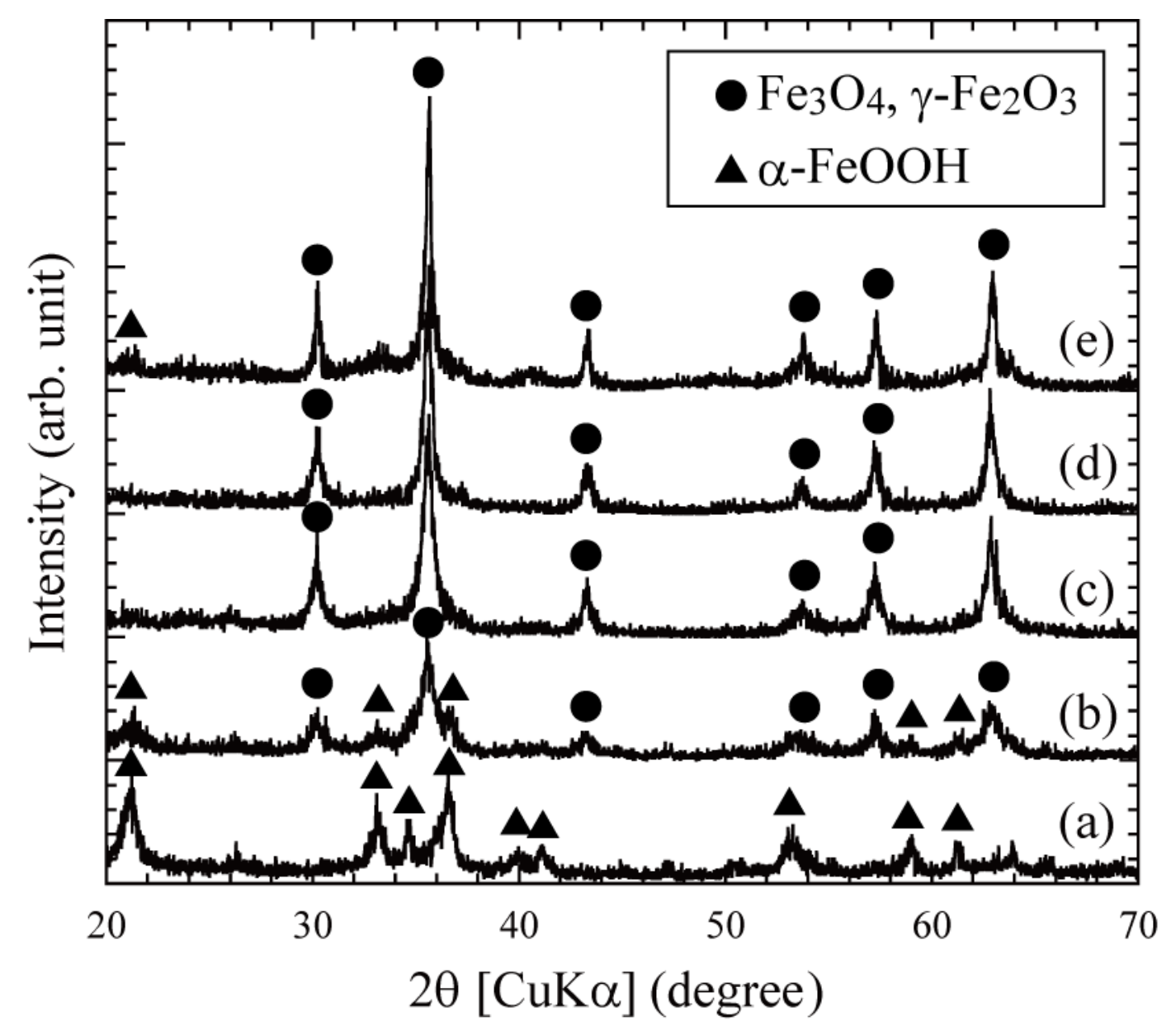

Fig. 1, Change of XRD pattern of co-precipitated particles after drying at $200^{\circ} \mathrm{C}$ with composition $\mathrm{x}$ in $\mathrm{xFeSO}_{4} \cdot 7 \mathrm{H}_{2} \mathrm{O}-(100-\mathrm{x}) \mathrm{FeCl}_{3}$. 


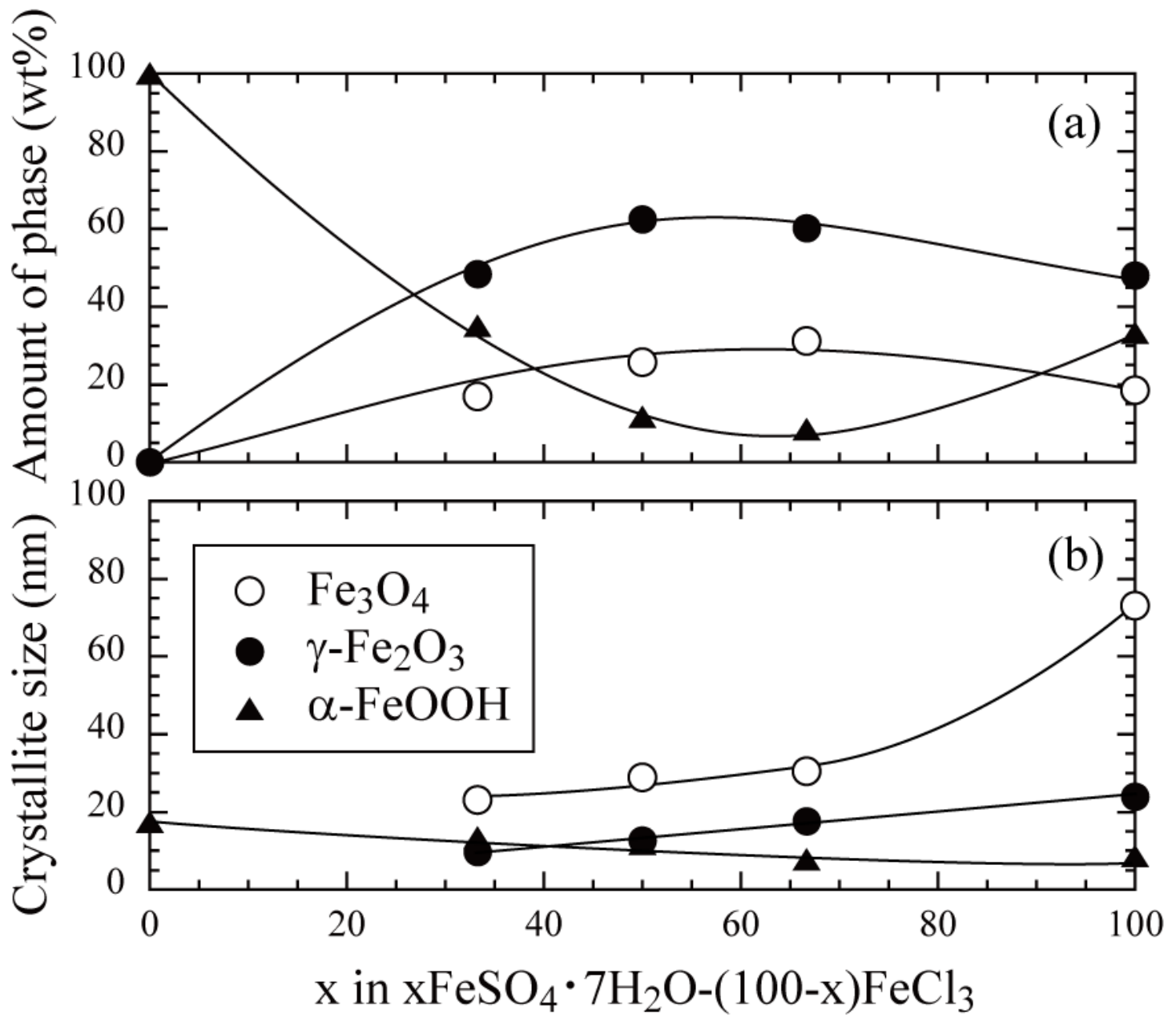

Fig. 2. Change of (a) amount of phase and (b) crystallite size with composition $x$ in $\mathrm{xFeSO}_{4} \cdot 7 \mathrm{H}_{2} \mathrm{O}-(100-\mathrm{x}) \mathrm{FeCl}_{3}$. The amount of phase and crystallite size was measured using TOPAS software [35]. 


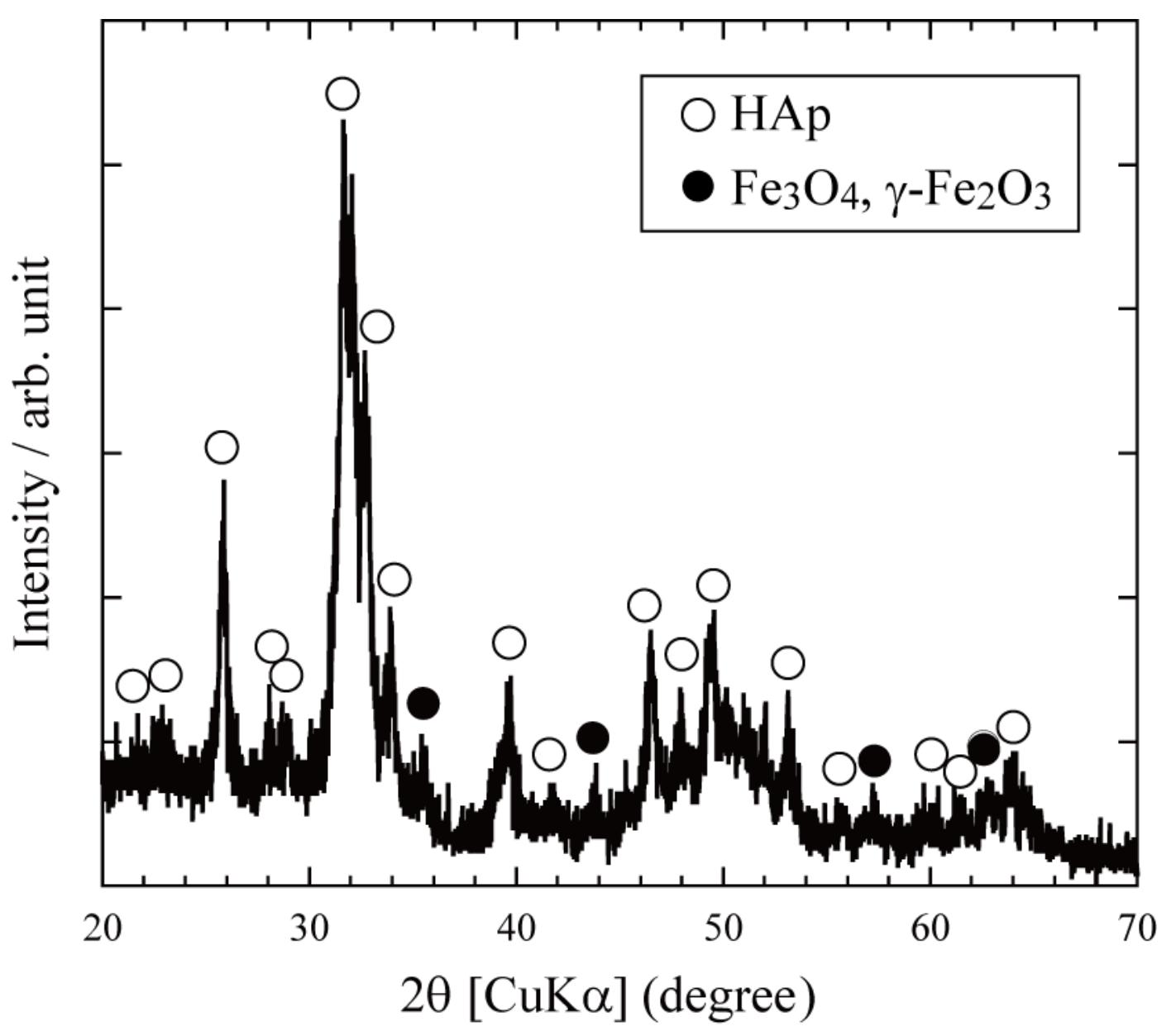

Fig. 3. XRD pattern of HAp-ferrite composite particles synthesized by two-step ultrasonic spray pyrolysis. 


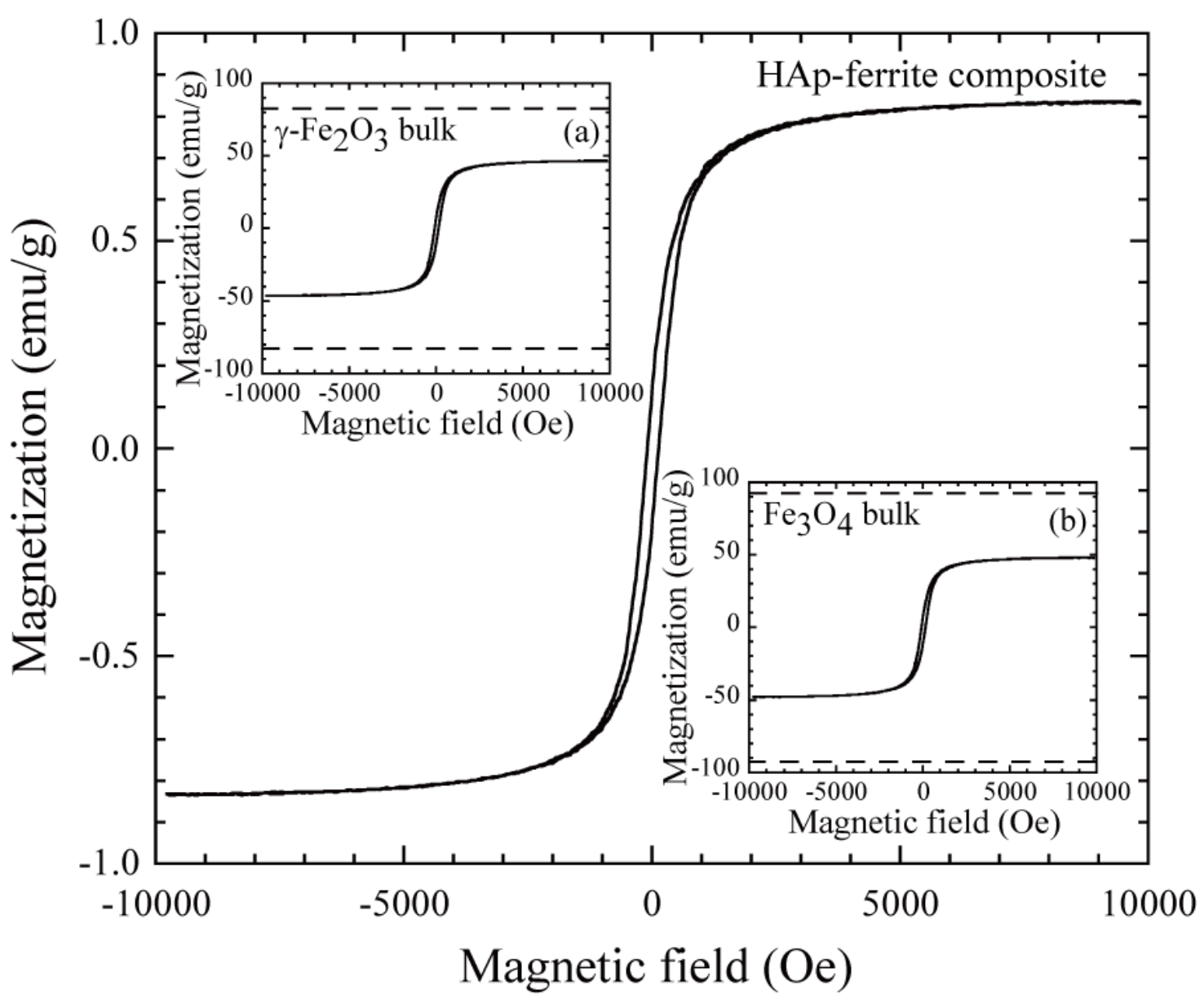

Fig. 4. M-H curve of HAp-ferrite composite particles synthesized by two-step ultrasonic spray pyrolysis. $\mathrm{M}-\mathrm{H}$ curve calculated on the assumption that all $\mathrm{Fe}$ ions are incorporated in $\gamma-\mathrm{Fe}_{2} \mathrm{O}_{3}$ and $\mathrm{Fe}_{3} \mathrm{O}_{4}$ is also shown as inset (a) and (b), respectively. 


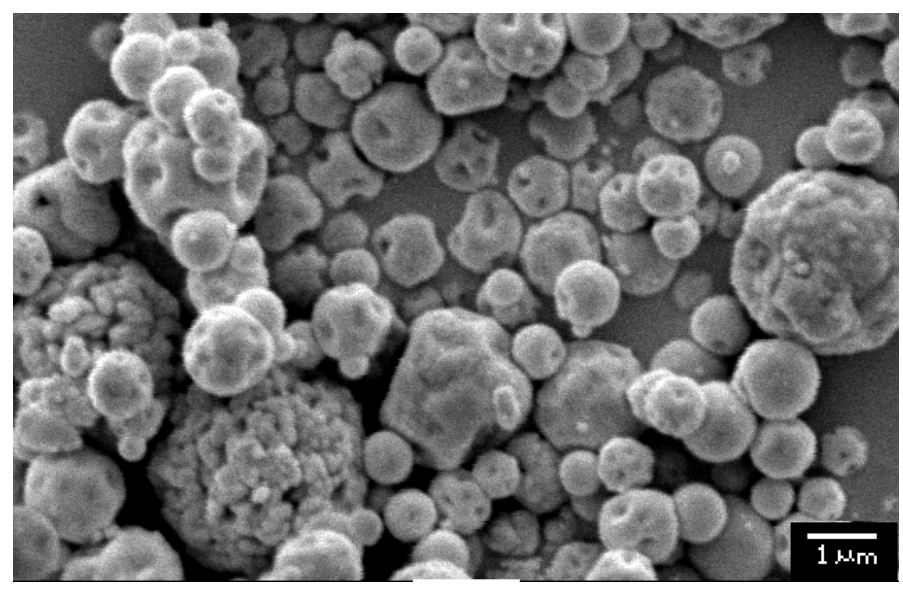

Fig. 5. SEM photograph of HAp-ferrite composite particles. 